\title{
ПРАВОВОЕ РЕГУЛИРОВАНИЕ ВОПРОСОВ ОБ ОТВЕТСТВЕННОМ ОБРАЩЕНИИ С ЖИВОТНЫМИ
}

\section{LEGAL REGULATION OF ISSUES ABOUT RESPONSIBLE TREATMENT OF ANIMALS}

S. Rybina

Summary. The article examines the features of legal regulation of issues of responsible treatment of animals. The grounds and conditions for the maintenance and protection of animals in the framework of Law №. 498-FZ are disclosed. Attention is focused on the problematic aspects of criminal and administrative responsibility for the protection of animals from abuse, ensuring the safety of citizens when interacting with them, and specific proposals are made to amend and Supplement the criminal code and administrative Code of the Russian Federation. Theoretical and practical aspects of walking a pet and its keeping conditions are analyzed. The article deals with the problematic aspects of organizing events in the implementation of activities for the treatment of animals without owners; protection of homeless animals; organizational and legal issues of the implementation of animal shelters.

Keywords: animal protection; cruelty to animals; responsible treatment of animals; chipping and recording of animals; animal shelters.

\author{
Рыбина Светлана Николаевна \\ К.б.н., дочент, Владимирский юридический \\ институm ФСИН России \\ rybina.sn@yandex.ru
}

Аннотация. В статье исследованы особенности правового регулирования вопросов об ответственном отношении с животными. Раскрываются основания и условия по содержанию и защите животных в рамках Закона № 498Ф3. Акцентируется внимание на проблемных аспектах уголовной и административной ответственности по защите животных от жестокого обращения, обеспечению безопасности граждан при взаимодействии с ними, и вносятся конкретные предложения по изменению и дополнению УК РФ и КоАП РФ. Анализируются, теоретико-практических аспекты выгула домашнего животного, условий его содержания. Рассматриваются проблемные стороны организации мероприятий при осуществлении деятельности по обращению с животными без владельцев; защиты бездомных животных; организационно-правовые вопросы осуществления деятельности приютов для животных.

Ключевые слова: защита животных; жестокое обращение с животными; ответственное обращение с животными; чипирование и учет животных; приюты для животных.
3 абота о животных - один из признаков цивилизованного общества. Современным обществом предложены поправки в Конституцию РФ, устанавливающие приоритет формирования в обществе ответственного отношения к животным, экологического воспитания и экологической культуры. Предлагаемая поправка в Основной закон РФ о защите животных важный вклад в воспитательную функцию государства. Через любовь, заботу и ответственное отношение к животным - формируется современное гуманное общеСтво.

Поэтому вслед за внесением поправок в Конституцию РФ должны последовать другие меры, в частности создание правовой системы, которая бы четко прописывала права и обязанности граждан в обращении с животными.

Первым шагом на пути к гуманизации взаимодействия человека и животного было принятие Федерального закон от 27.12.2018 № 498-Ф3 «Об ответственном обращении с животными и о внесении изменений в отдельные законодательные акты Российской Федерации» (далее Закон № 498-Ф3), которого в России ждали 8 лет.

С 1 января 2019 года вступили в силу базовые нормы закон об ответственном обращении с животными, однако отдельные положения закона вступают в силу с 1 января 2020 года.

Закон № 498-Ф3 предусматривает меры по защите животных от жестокого обращения и обеспечению безопасности граждан при взаимодействии с ними. Настоящий Федеральный закон включает в себя понятийный аппарат, устанавливает полномочия федеральных органов государственной власти, органов государственной власти субъектов Российской Федерации, полномочия и права органов местного самоуправления в области обращения с животными, регламентирует требования к содержанию и использованию животных, устанавливает требования к осуществлению деятельности по обращению с животными без владельцев [1]. 
В данный Закон № 498-ФЗ заложены основные нравственные и гуманные принципы (ст. 4 Закона), которые действуют во многих европейских странах. Отношение к животным как к существам, способным испытывать эмоции и физические страдания:

- животных нельзя убивать ни под каким предлогом;

- не допускается использование домашних животных в предпринимательской деятельности, за исключением случаев, установленных Правительством Российской Федерации;

- не допускается жестокое обращение с животными;

- запрет на пропаганду жестокого обращения с животными;

- требования к использованию животных в культурно-зрелищных целях, не причиняя вреда их жизни и здоровью.

С другой стороны, Закон № 498-Ф3 также защищает права человека, обеспечивая защиту людей от угрозы причинения вреда их жизни:

- вводится порядок выгула собак, в том числе потенциально опасных пород [2];

- запрет на содержание диких животных в квартиpax [3], и перечень случаев содержания диких животных, запрет на которых не распространяется [4];

- натравливание животных на людей, за исключением случаев необходимой обороны, использования служебных животных в соответствии с законодательством Российской Федерации или дрессировки собак кинологами;

- организаторы мероприятий, в которых осуществляется использование животных в культурно-зрелищных целях, обязаны обеспечивать безопасность людей.

Также Законом № 498-ФЗ установлено, что за нарушение требований настоящего Федерального закона владельцы животных и иные лица несут административную, уголовную и иную ответственность в порядке, установленном законодательством Российской Федерации.

Таким образом, данный Закон № 498-Ф3 должен был повлечь за собой изменения в кодексах уголовном и об административных правонарушениях.

Уголовная ответственность за жестокое обращение с животными предусмотрена статьей 245 УК РФ, которая претерпела изменения и дополнения с принятием Закона № 498-Ф3.

Данная статья УК РФ содержится в Главе 25. «Преступления против здоровья населения и общественной нравственности». Анализируя состав правонарушения, необходимо отметить, что субъектом могут являться обвиняемые, достигшие 16 лет.

По нашему мнению, за совершение правонарушения необходимо снизить возраст субъекта ответственности за живодерство с 16 до 14 лет, т.к. в этом возрасте человек уже является состоявшейся личностью и гражданином, который вполне готов нести ответственность за свои поступки, тем более за поступки подобного рода, касающиеся жестокого обращения с животными, поскольку в дальнейшем, данное безответственное поведение может проецироваться уже в том числе и на человека.

Касаемо административной ответственности, предлагается внести следующие изменения и дополнения в кодекс об административных правонарушениях:

1. Статью 5.7. Совершение жестоких действий в отношении животных, дополнить п. 6. «за проведение на животных без обезболивания ветеринарных и иных процедур, которые могут вызвать непереносимую боль» влечет наложение административного штрафа на граждан в размере от двух тысяч до двух тысяч пятиcom рублей; на должностных лиц - от четырех тысяч до пятнадцати тысяч рублей; на юридических лиц - от пятидесяти тысяч до ста тысяч рублей.

2. Статью 5.1. Нарушение правил содержания домашних животных, дополнить п. 8. «за натравливание домашнего животного на людей или животных за исключением случаев необходимой обороныл» влечет наложение административного штрафа на граждан в размере от двух тысяч до пяти тысяч рублей; на должностных лиц от пяти тысяч до тридиати тысяч рублей, помещзать на административный арест сроком до 30 суток.

Проблема бездомных животных должна решаться комплексно, и это не только ужесточением ответственности, но и уточнением списка субъектов, например, рассмотреть такую категорию, как дачники, которые заводят домашних животных, а по окончанию дачного сезона безответственно бросают их.

Закон № 498-Ф3 п. 2 ст. 9 предусмотрел неоднозначное требование, которое не разрешает владельцу избавляться от питомца при невозможности его дальнейшего содержания, а обязан передать его новому владельцу, либо в приют, но при этом сразу возникает вопрос: «Как данные факты будут фиксировать на практике?». Прежде всего необходимо доказать, что данное животное принадлежит конкретному владельцу, а это 
становится возможным, с помощью процедуры чипирования.

31 декабря 2019 г Минсельхоз внес на рассмотрение в правительство законопроект «О внесении изменений в отдельные законодательные акты РФ в части совершенствования законодательства в сфере ветеринарии», который был одобрен, сейчас его подготавливают для рассмотрения в Госдуме.

Согласно документу, владельцев домашних животных обяжут ставить на учет и чипировать своих питомцев, при этом сама процедура будет бесплатной для граждан. Кроме того, в России предлагается создать единый федеральный реестр животных.

Но, на сегодняшний день имеют место и иные объективные причины, по которым не наступает ответственность по отдельным запретам Закон № 498-Ф3. Например, п. 5. ст. 9 Закона № 498-ФЗ прописывает обязанность владельцев убирать биологические отходы за своими питомцами, для чего, полагаем, необходимо во время прогулок владельцам иметь при себе совок и пакет. Но, остается открытым вопрос с утилизацией отходов жизнедеятельности питомцев, поскольку данные отходы должны складироваться не в обычных урнах, а в специализированных дог-боксах, которые пока мало распространены.

Также необходимо время для того, чтобы начали работать отдельные нормы закона, например, п .5. ст. 13 Закона № 498-Ф3 обязывает владельца не допускать выгул животного вне мест, разрешенных решением органа местного самоуправления для выгула животных. Но, для начала муниципалитету необходимо создать соответствующие определенным требованиям территории для выгула собак с общей площадью не менее 400 кв.м. При этом зона выгула должна располагаться в отдалении от жилых домов и офисных зданий (минимум 25 м); нельзя выгуливать питомца на участке, который находится ближе, чем в 40 м от детских учреждений (садики, площадки, школы, больницы); покрытие, использующееся на территории выгула, необходимо менять минимум раз в год [5].

Недоработанным в законодательстве является п. 3. ст. 13 Закона № 498-Ф3 «Предельное количество домашних животных в местах содержания животных определяется исходя из возможности владельца обеспечивать животным условия, соответствующие ветеринарным нормам и правилам, а также с учетом соблюдения санитарно-эпидемиологических правил и нормативов». Размытая формулировка не дает нам понимания о том, сколько животных можно содержать в квартире или ином помещении, в каких именно условиях они должны содержаться, что именно является нарушением содержания животных.

Особое внимание уделено Законом № 498-Ф3 организационно-правовым вопросам осуществления деятельности приютов для животных. Теперь, приюты не могут размещаться в квартирах и домах любой формы собственности, в соответствии с п. 2. ст. 16 Закона № 498Ф3 «Приюты для животных размещаются в специально предназначенных для этого зданиях, строениях, сооружениях». Что безусловно защищает права и законные интересы соседей. Но, как утверждают зооактивисты, данные требования законодательства повлекут за собой уменьшение возможности частным волонтерам содержания животных, в том числе бездомных.

Приюты в соответствии с п. 4. ст. 16 Закона № 498-Ф3 «Владельцами частных приютов для животных могут быть индивидуальные предприниматели или юридические лица», т.е. приюты должны быть оформлены как коммерческие организации. Таким образом благотворительность стала бизнесом и деятельностью, приносящей доход. Возникает вопрос: «За счет какой именно деятельности предполагается получать доход?»

Необходимо отметить, что на данный момент одной из основных проблем приютов для животных не зависимо от форм собственности является финансирование мероприятий по маркировке, стерилизации и вакцинации поступивших в приют животных. Закон № 498-Ф3 не уточняет на какие средства планируется содержать приюты для животных, от которых отказались владельцы в соответствии со п. 2 ст. 9 «В случае отказа от права собственности на животное или невозможности его дальнейшего содержания владелец животного обязан передать его новому владельцу или в приют для животных, которые могут обеспечить условия содержания такого животного».

Таким образом, главным требованием Закона № 498Ф3 наряду с положениями о защите животных является обеспечение безопасности людей и животных, сохранности имущества физических или юридических лиц, а также соблюдение обязательных требований при выгуле домашних животных, уменьшение случаев жестокого обращения с животными, комфортное содержание животных. Но при глубоком анализе данного нормативно-правового акта складывается двоякое мнение. С одной стороны, принятие данного закона - это необходимый и важный шаг к гуманизации. Но с другой стороны, не смотря на многолетнее обсуждение, закон во многом декларативен, поскольку его выполнение не обеспечено ни финансово, ни организационно и требует в том, числе существенных законодательных уточнений и дополнений. 


\section{ЛИТЕРАТУРА}

1. Прокурор разъясняет: 06 ответственном обращении с животными. - URL: https://kamprok.ru/prokuror-razyasnyaet-ob-otvetstvennom-obrashhenii-szhivotnymi/ (дата обращения: 12.05.2020).

2. $0 б$ утверждении перечня потенциально опасных собак: постановление Правительства РФ от 29 июля 2019 г. № 974 // publication.pravo.gov.ru 0фициальный интернет-портал правовой информации. Государственная система правовой информации.

3. $0 б$ утверждении перечня животных, запрещенных к содержанию: постановление Правительства РФ от 22 июня 2019 г. № 795 // publication.pravo.gov.ru Официальный интернет-портал правовой информации. Государственная система правовой информации.

4. 06 утверждении перечня случаев, при которых допускаются содержание и использование животных, включенных в перечень животных, запрещенных к содержанию: постановление Правительства РФ от 27 июня 2019 г. № 819 // publication.pravo.gov.ru 0фициальный интернет-портал правовой информации. Государственная система правовой информации.

5. Закон о выгуле собак в 2020 году. — URL: https://zakonoved.su/zakon-o-vygule-sobak.html (дата обращения: 15.05.2020).

( Р Рыбина Светлана Николаевна ( rybina.sn@yandex.ru ).

Журнал «Современная наука: актуальные проблемы теории и практики»

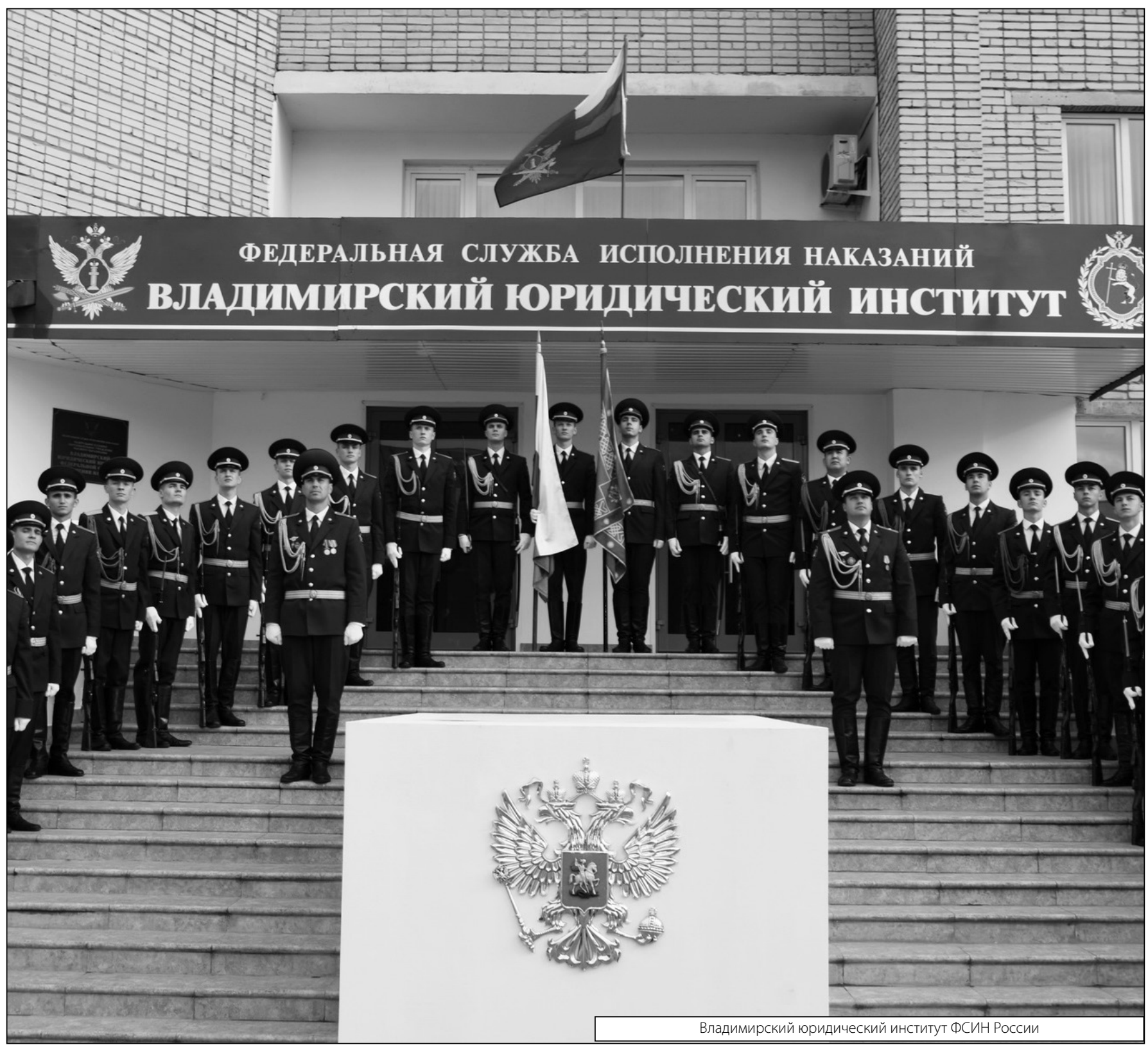

